\title{
Compliance and complications of clean intermittent catheterization in the spinal cord injured patient
}

\author{
T Chai, AK Chung, WD Belville and GJ Faerber \\ Section of Urology, Department of Surgery, University of Michigan Medical Center, 1500 E Medical Center \\ Drive, Ann Arbor, MI 48109-0330, USA
}

\begin{abstract}
The optimal management of the neuropathic bladder secondary to spinal cord injury remains unsettled. Some have advocated the use of chronic indwelling catheters in tetraplegic patients supposedly due to comparable complication rates with non-indwelling catheter management. We assessed the urological complication and compliance rates in a group of spinal cord injured patients followed over a mean of 5.9 years. Complication rates from clean intermittent catheterization were comparable if not better than the rates previously reported for clean intermittent catheterization and significantly better than chronically catheterized patients. The compliance rate in our series was $71 \%$ as determined by the number of patients remaining on clean intermittent catheterization at their last urological follow-up. We conclude that the use of clean intermittent catheterization can provide optimal management of the lower urinary tract in spinal cord injured patients.
\end{abstract}

Keywords: intermittent catheterization; complications; compliance; neuropathic bladder; indwelling catheter

\section{Introduction}

Management of the neuropathic bladder resulting from spinal cord injury (SCI) remains controversial. Recently, Dewire et al reported no significant differences in the detrimental effects in tetraplegic patients managed with chronic indwelling catheters compared to those without chronic catheters. ${ }^{1}$ Alternatively, other reports have shown that intermittent catheterization is a good treatment for the neuropathic bladder..$^{2-8}$

We addressed the long term complication rate of clean intermittent catheterization (CIC) in a large spinal cord injury population. These individuals were routinely followed up by both urologists and by physical medicine and rehabilitation physicians. Our goal in this population was long term utilization of CIC unless unusual physical or social problems disallowed this method. We reviewed the compliance rate of CIC as well as complications due to bladder calculi, renal calculi, pyelonephritis, urosepsis, gross hematuria, urethral erosions, urethral strictures, and epididymitis. We contrasted these complication rates to those previously reported in the literature..$^{1,5-8}$

\section{Material and methods}

The cohort consisted of 89 individuals with spinal cord injuries from 1985 to 1989 presenting to our institution. Data were collected from our local Spinal Cord Registry Database as well as chart review. The data recorded included urological complications, level and extent (Frankel classification) of spinal cord injury, length of follow-up, most recent upper tract status (either by renal ultrasound or IVP), urological procedures performed, and whether or not the patient was continued on CIC.

The management of these individuals routinely included CIC after short term Foley catheter drainage for treatment in the period of initial spinal shock. Urodynamics (CMG and/or fluorourodynamics) were routinely performed to document the maintainence of low pressure bladder storage $(<40 \mathrm{~cm} \text { water })^{9}$ and oral anticholinergics added as necessary. If patients were unable to maintain a low storage pressure despite maximum anticholinergic therapy, bladder augmentation was frequently recommended. Routine upper tract evaluation with either ultrasound or IVP as well as cystoscopy was performed regularly.

A precise follow-up protocol for $\mathrm{CIC}$ which has been previously described was maintained for these individuals. $^{2-6}$ This process involved vigorous patient education as well as substantial nursing supervision.

\section{Results}

The mean follow-up interval was almost 6 years $(5.9$ years). Of the 89 individuals who presented to us during the time period between 1985 to 1989 who were originally begun on CIC, $63(71 \%)$ of these individuals have remained on CIC. The demographics of this group of 63 patients is shown in Table 1. Most of these SCIs were complete by the Frankel classification. Fortyeight $(76 \%)$ fit the classification for Frankel $\mathrm{A}, 10$ (16\%) for Frankel B, 5 (8\%) for Frankel C, and 0 for Frankel D. 
Table 1 Demographics of patients who remained on CIC $(n=63)$

\begin{tabular}{ll}
\hline Median age (range) & $25(2-73)$ \\
Male:female ratio & $3.8: 1$ \\
Level of injury & $31(49 \%)$ C-spine \\
& $25(40 \%)$ T-spine \\
& $7(11 \%)$ L-spine \\
Mean follow-up (range) & 5.9 years (4 months-8.5 years)
\end{tabular}

The bladder management of those 26 patients found not to be maintained on CIC included spontaneous voiding (15) Foley or SP tube (6), condom catheter (2), Credé voiding (1), and unknown (3). Overall, 11 of the 63 patients $(17 \%)$ required at least one other urological procedure, including bladder augmentation (4), bladder suspension (3), collagen injection (4), and continent vesicostomy (1).
We compared our complication rates with those published in the literature for patients on CIC (Table 2 ), finding most of our rates to be lower. When we compared our complication rates in tetraplegic patients with that reported for chronically catheterized tetraplegic patients by Dewire, ${ }^{1}$ we found a significantly lower complication rate based on a $t$ test assuming a binomial distribution (Table 3 ).

\section{Discussion}

Since Lapides et al introduced the technique of clean intermittent self-catherization in 1972, it has gained wide acceptance in the treatment of the SCI patient. ${ }^{2}$ There have been several reports showing a low incidence of serious complications with this technique despite early widespread skepticism..$^{2-4}$ We focused on the incidence of long term complications, finding the results comparable or better to prior reports with a

Table 2 Comparison of compliance and complication rates of patients on CIC

\begin{tabular}{|c|c|c|c|c|c|}
\hline & $\begin{array}{l}\text { Maynard and } \\
\text { Diokno }\end{array}$ & $\begin{array}{l}\text { Maynard and } \\
\text { Diokno }\end{array}$ & $\begin{array}{l}\text { Maynard and } \\
\text { Glass }^{7}\end{array}$ & $\begin{array}{l}\text { Perkash and } \\
\text { Gerioux }\end{array}$ & $\begin{array}{l}\text { Current } \\
\text { study }\end{array}$ \\
\hline \multicolumn{6}{|l|}{ Patients } \\
\hline Mean follow-up & 3.7 years & 50 days & 5.1 years & 22 months & 5.9 years \\
\hline No. of subjects on CIC & 28 & 50 & 34 & 31 & 63 \\
\hline \multicolumn{6}{|l|}{ Complications } \\
\hline Renal stones & $3(11 \%)$ & a & $2(6 \%)$ & a & $1(1.6 \%)$ \\
\hline Bladder stones & $3(11 \%)$ & $1(2 \%)$ & $6(18 \%)$ & $3(10 \%)$ & $6(9.5 \%)$ \\
\hline Pyelonephritis & $0(0 \%)$ & a & a & a & $1(1.6 \%)$ \\
\hline Gross hematuria & a & $5(10 \%)$ & a & a & $2(3.2 \%)$ \\
\hline Urethral erosions & 0 & a & a & a & $0(0 \%)$ \\
\hline Urosepsis & a & $3(6 \%)$ & a & a & $1(1.6 \%)$ \\
\hline Urethral strictures & a & a & $2(6 \%)$ & a & $2(3.2 \%)$ \\
\hline Epididymitis & $4(14 \%)$ & a & $3(9 \%)$ & $5(16 \%)$ & $7(11.1 \%)$ \\
\hline $\begin{array}{l}\text { Difficulty in catheterizing/false } \\
\text { passage }\end{array}$ & a & a & $1(3 \%)$ & $1(3 \%)$ & $2(3.2 \%)$ \\
\hline Compliance & a & a & $82 \%$ & $34 \%$ & $71 \%$ \\
\hline
\end{tabular}

aNot available

Table 3 Comparison of complication rates from CIC versus chronic indwelling catheter in tetraplegic patients

\begin{tabular}{|c|c|c|c|}
\hline & $\begin{array}{l}\text { Current study } \\
(\text { (CIC) }\end{array}$ & $\begin{array}{c}\text { Dewire et al } \\
\text { (chronic catheter) }^{I}\end{array}$ & $P$ value \\
\hline $\begin{array}{l}\text { Patients } \\
\text { No. of subjects on CIC }\end{array}$ & 31 & 32 & \\
\hline $\begin{array}{l}\text { Complications } \\
\text { Renal stones } \\
\text { Bladder stones } \\
\text { Pyelonephritis } \\
\text { Gross hematuria } \\
\text { Urethral erosions } \\
\text { Urosepsis } \\
\text { Urethral strictures } \\
\text { Epididymitis } \\
\text { Difficulty in catheterizing/false passage }\end{array}$ & $\begin{array}{l}1(3 \%) \\
5(16 \%) \\
0(0 \%) \\
1(3 \%) \\
0(0 \%) \\
0(0 \%) \\
0(0 \%) \\
2(6 \%) \\
1(3 \%)\end{array}$ & $\begin{array}{c}8(25 \%) \\
13(41 \%) \\
8(25 \%) \\
2(6 \%) \\
4(12.5 \%) \\
2(6 \%) \\
3(9 \%) \\
2(6 \%) \\
0 \%\end{array}$ & $\begin{array}{c}<0.05 \\
<0.05 \\
<0.05 \\
\text { NS } \\
<0.05 \\
\text { NS } \\
\text { NS } \\
\text { NS } \\
\text { NS }\end{array}$ \\
\hline
\end{tabular}

NS $=$ Not significant 
shorter follow-up. ${ }^{5-8}$ This review confirmed those earlier findings of a low rate of long term complications with the technique of $\mathrm{CIC} .^{5-8}$

The optimal management of the neuropathic bladder in SCI is multifactorial. We believe that ideal lower urinary tract management consists of the use of CIC combined with medical therapy to maintain a low bladder storage pressure. When contrasted to indwelling tubes, our results showed superior long term results. ${ }^{1}$ Despite differences in the follow-up time between our study and that of Dewire's, CIC patients seem to do significantly better than those who were chronically catheterized, and we feel that they are free from the serious sequelae of foreign body induced bladder malignancy. However, the chronically noncatheterized group of patients in the Dewire study was heterogeneous and included those on CIC, condom catheter drainage, spontaneous voiding, and urinary diversion. Continued long term follow-up is needed to reaffirm our findings.

We do not comment on bacteriuria in this work. We believe that asymptomatic bacteriuria in patients on $\mathrm{CIC}$ is common, and generally not of clinical significance, as is discussed by Lapides et al, ${ }^{2-4}$ McGuire et $a l^{9}$ and Kass et al.$^{10,11}$ We feel that bacteriuria without significant pyuria is rarely of clinical consequence in these patients. Additionally, the presence of a fever in a SCI patient may not necessarily be related to the urinary tract despite a positive urine culture since the incidence of bacteriuria in spinal cord patients with fever is equivalent to those without..$^{9}$

It should be emphasized that a program of CIC is demanding, requiring excellent patient compliance. CIC requires great mental and physical capacity, and strict self-discipline. Patient compliance and the physical capacity of good hand function, or the availability of a 24-h aide must be present before starting the spinal cord injury patient on CIC. Also, specific protocols should be followed to ensure that the proper technique is used consistently, a frequent regular schedule utilized, and a low bladder pressure maintained. In addition, physicians and ancillary staff need to reinforce these principles during the follow-up period. This report shows that even among a mostly tetraplegic population, compliance with CIC can be fairly well maintained over a long follow-up period.

\section{Conclusions}

This work shows that CIC continues to be an effective long term form of therapy for the neuropathic bladder in the SCI population. The long term complication rate is quite acceptable especially when compared to treatment alternatives. We also showed a high compliance rate with $\mathrm{CIC}$ over the long term despite having a high proportion of tetraplegic patients. CIC should be the long term management of choice for the lower urinary tract in the spinal cord injured.

\section{References}

1 Dewire DM et al. A comparison of the urologic complications associated with long-term management of quadriplegics with and without chronic indwelling urinary catheters. J Urol 1992; 147: 1069 .

2 Lapides $\mathrm{J}$ et al. Clean intermittent self-catheterization in the treatment of urinary tract disease. J Urol 1972; 107: 458.

3 Lapides J, Diokno AC, Lower BS, Kalish MD. Follow-up on unsterile intermittent self-catheterization. J Urol 1974; 111: 184.

4 Lapides J, Diokno AC, Gould FR, Lowe BS. Further observations on self-catheterization. J Urol 1976; 116: 169.

5 Maynard FM, Diokno AC. Clean intermittent catheterization for spinal cord injured patients. J Urol 1982; 128: 477.

6 Maynard FM, Diokno AC. Urinary infection and complications during clean intermittent catheterization following spinal cord injury. J Urol 1984; 132: 943.

7 Maynard FM, Glass J. Management of the neuropathic bladder by clean intermittent catheterization: 5 year outcomes. Paraplegia 1987; 25: 106.

8 Perkash I, Giroux J. Clean intermittent catheterization in spina cord injury patients: a followup study. J Urol 1993; 149: 1068.

9 McGuire EJ, Noll F, Maynard F. A pressure management system for the neurogenic bladder after spinal cord injury. Neurourol Urodynam 1991; 10: 223.

10 Kass EJ, Koff SA, Diokno AC. Fate of vesicoureteral reflux in children with neuropathic bladders managed by intermittent catheterization. J Urol 1981; 125: 63.

11 Kass EJ, Koff SA, Diokno AC, Lapides J. The significance of bacilluria in children on long term intermittent catheterization. J Urol 1981; 126: 223. 